\title{
RETIREMENT PLANNING: YOUNG PROFESSIONALS IN PRIVATE SECTOR
}

\author{
Ainol Sarina Ahmad Zazili*, Mohammad Firdaus Bin Ghazali**, Norlinda Tendot Binti Abu

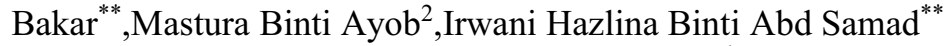 \\ Faculty of Accountancy, Universiti Teknologi MARA Melaka*, Faculty of Business \& \\ ManagementUniversiti Teknologi MARA Melaka**
}

\begin{abstract}
The purpose of this study is to determine the factors influencing retirement planning among young professionals in private sector. There are three factors identified in this research which includes financial literacy, job satisfaction and savings behavior. Data used for this study are primary and secondary data such as from journal articles, periodicals and textbooks. A questionnaire is distributed and administered to extract data from the respondents consist of executives, non-executives and managers around Klang Valley, aged between 20 - 34 years old. The data is analyzed using frequency analysis, reliability test and Pearson correlation in order to obtain a clear findings and results. The findings show that financial literacy, job satisfaction and savings behavior has a positive association towards retirement planning. Furthermore, it is shown that financial literacy and saving behavior have a significant relationship with retirement planning. It is hope that this study will inform and encourage the young professionals to save and invest for the retirement.
\end{abstract}

Keywords: Retirement Planning, Young Professionals, Financial Literacy, Job Satisfaction and Saving Behavior

\section{INTRODUCTION}

This research paper discusses retirement planning among young professionals in private sector and factors that can be an encouragement for them to plan for the retirement. The concern over retirement planning is not only an interest of employees but also government. One of the retirement planning introduced by the Malaysian government is Employee Provident Fund (EPF) pension where every employee has been required to make a mandatory contribution to the Employee Provident Fund (EPF) pension scheme. The EPF is a social security institution formed according to the Laws of Malaysia, Employees provident Fund Act 1991 (Act 452) which provides retirement benefits for members. The members of EPF are from private and non-pensionable public sector employees. Currently, the employees' monthly statutory contribution rate reduced from $11 \%$ to $8 \%$ for members below age 60 and 5.5\% to 4\% for those age 60 and above, effective March 2016 until December 2017 salary.

Even though workings individuals in Malaysian private sectors have savings with EPF pension scheme, it is not guarantee that their fund is sufficient for retirement because it takes many years to accumulate financial fund to live comfortably during retirement. Some employees are concern about his EPF and some might not. Surprisingly, study has found that younger generation of workings individuals in private sectors perceived that retirement planning is a burden for them because it involves long-term planning (Moorthy, et al., 2012). If this issue is not addressed appropriately, employees' especially young professionals in private sectors may face the problems in their retirement life. Therefore, it is very crucial to identify the factors that lead the employees to plan for their retirement. Some of the factors discussed by prior literatures are financial literacy (Potts, 2013, Moorthy et al, 2012 \& Lusardi \& Mitchell, 2011), job satisfactions (Schultz \& Wang 2010) and savings behavior (Stawski, Hershey \& Jacobs-Lawson, 2007). There is a limited prior study done in

*Corresponding author's email: ainol1776@bdrmelaka.uitm.edu.my 
Malaysia toward the association of retirement planning with financial literacy, job satisfaction and saving behavior especially among young professional working in private sector. Therefore, this research is done and questionnaires are distributed to 100 respondents of young professionals in private sectors around Klang Vallley area. The main purpose of this study is to determine the association between retirement planning with financial literacy, job satisfaction and savings behavior. Other than that, this research is intended to present the demographic profiles of young professionals in private sector towards the retirement planning.

\section{LITERATURE REVIEW}

This section provides literature review from various researchers on the association of retirement planning with financial literacy, job satisfaction and savings behavior.

Lusardi \& Mitchell (2007) reviewed international evidence on financial literacy and found that financial illiteracy is common in many develop countries such as Australia, Japan, Korea as well as develop countries in Europe. A few studies have shown that retirement planning and financial literacy are interrelated. Individuals' inability to make self-beneficial financial decisions relating to consumer financing can have negative implications on the entire economy (Klein, Mandell \& Schmid, 2009). Therefore, every individual is responsible for their own financial decisions in order to diversify its planning for better future in term of being the purchase and financing of a home and preparing for retirement (Hung, Parker \& Yoong, 2009). There is evidence in a study done by Klein, Mandell \& Schmid (2007) found that financial behavior is positively affected by financial literacy but it will be less certain for long term period if financial education on financial behavior is not practiced by young generation. Thus, lack of literacy and financial sophistication is critical because they have important consequences for lifetime wellbeing (Lusardi \& Mitchell, 2011).

Research on the relationship between job satisfaction and retirement is quite limited. Study done by Clark, Mavromaras \& Wei (2014) has found significant relationship between job satisfaction and retirement planning. Further, they explained the retirement decision of those who are currently active in the labor market and the job satisfaction on retirement, while significant for both males and females, is slightly stronger for females. Also, job satisfaction was found to be one of the factors that encourage plan for retirement. This kind of relationship perhaps will enhance individual's work related attitudes from time-to-time (Dendinger, Gary \& Jacobson, 2005). This is supported by a study done by DeVaney $\&$ Chen (2003) which describes the attitude toward the job is related to their relationships with superior, top management and co-worker because it is an essential element of job satisfaction in order to have more of a sense of control to their retirement planning.

Another study found that there is a link between saving behavior with retirement planning. Lusardi (2003) states many individuals perform poor savings behavior as they assume that planning for retirement is a difficult task until they will experience that it is too late to make decision for retirement. Gedela \& Prakasa (2012) even suggested that the tendency to save should be raised by appropriate incentives and policies since better retirement planning can be put in place with the higher domestic savings. For instance the strategy used to motivate employee involvement in retirement plan known as automatic enrollment (or negative election), has been proved to amplify enrollment in U.S. defined contribution plans (Benartzi \& Thaler, 2007). Additionally, every employees is responsible for their own savings decisions in order to accumulate sufficient resources and have adequate retirement fund at the desired age and they must know to decide when to start saving, how much to save and how to invest their money to generate income during retirement period (Clark, d'Ambrosio, McDermed \& Sawant, 2003). If most of potential retirees having lack of information about saving or investing for retirement, they will fail to plan ahead and take on financial risks without realizing it (Mbazigwe, 2013).

Based on a review of relevant literatures discussed above, there are two types of variables identified in this research. First variable is retirement planning which is the dependent variable. The second variable 
is independent variables such as financial literacy, job satisfaction and saving behavior. Figure 1 illustrates the theoretical framework of this research.

Independent Variable 1

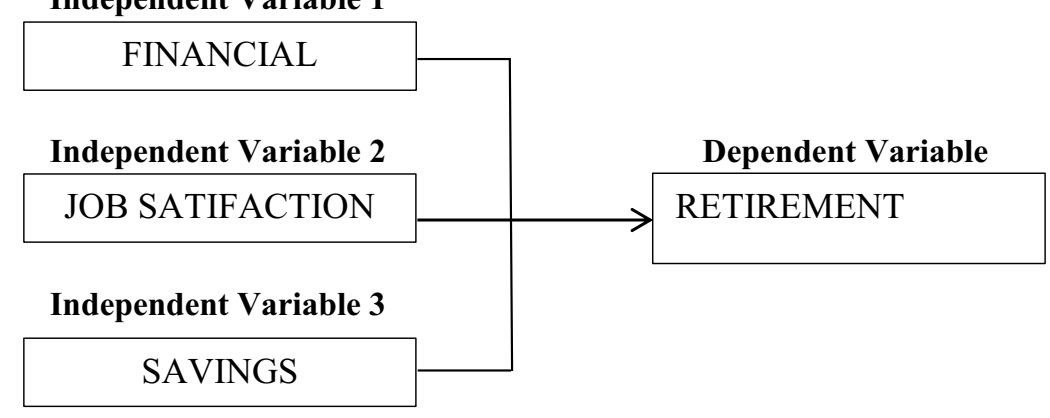

Figure 1: Theoretical Framework

\section{RESEARCH METHODOLOGY}

This part explained the method used for the collection of data, presentation and analysis of data. The questionnaires has been used to collect the information needed from young professional in private sectors around Klang-Valley who aged between 20 until 34 years old, consists of executive, nonexecutive and manager. According to the United Nations, Educational, Scientific and Cultural Organization (UNESCO) 'youth' is defined as those persons between the ages of 15 and 24 years. The ages between 15 to 24 years is not suitable to be used in this study because it only includes group of young teenagers who are still studying in secondary high schools or universities and not many of them get employed in Malaysian private and public sectors. In 1997, The National Youth Development Policy of Malaysia defines 'youth' as people between 15 to 40 years old. The young persons in his or her 20s or early 30 s who is employed as a manager, or administrators in the organization would be considered a young professional while someone occupying the same position but had reached the age of 40 s would be labeled as a professional, but not necessarily classified as young. Meanwhile, young professionals, as chosen in this study focus only on executive, non-executive and managers aged between 20 through 34 who are working in private sectors. They are selected because it is felt that these group are very likely to have valuable insight regarding what factors would be the most important when planning for retirement. The distribution of the questionnaires is generally to any private sectors employees without focus on any specific gender or position. The sample size in this research paper is limited to 100 respondents since the research paper must be finished in a short period. However, this sample size is considered appropriate for this research. As mentioned by Roscoe (1975) the rules of thumb for determining the sample size, the sample size should be larger than 30 and less than 500. The data is analyzed using IBM SPSS Statistic Data Editor to conduct frequency analysis and reliability analysis, mean analysis, Pearson correlation analysis, and regression analysis.

\section{FINDINGS AND ANALYSIS}

\section{Frequency Analysis (Demographic Profiles)}

Frequency analysis is used to measure the percentage of the respondents in term of their gender, age, race, religion, education level, marital status, employment status, position and monthly salary. Table 1 displays the demographic characteristics analysis among the young professional in private sector. Majority of the respondents are female $(61.0 \%)$ and male only at 39.0 percent. Respondents aged between 24 to 27 years old contribute $44.0 \%$ from the overall respondents that answering the questionnaire, followed by $25.0 \%$ from aged 28 to 31 years old, $17.0 \%$ from aged 32 to 34 years old 
and only $14.0 \%$ from aged 20 to 23 years old. It's clearly shown that the majority of the respondents are Malay $(92.0 \%)$, followed by Chinese, Indian and other race with percentage contribution are $5.0 \%$, $2.0 \%$ and $1.0 \%$ respectively.

Table 1 shows the educational background of respondents at different levels of education which are SPM/STPM, professional certificate, diploma, degree and master level. Majority of the respondents possess a degree certificate with percentage of 55.0\%. 23 respondents holding diploma certificate, SPM/STPM (16.0\%), Professional Certificate (4.0\%) and the least are possessed by Master holder which is only $2.0 \%$. Majority of the respondents are single with contribution percentage are $59.0 \%$ of overall respondents, while $41.0 \%$ are married.

Table 1: Demographic Characteristics Analysis

\begin{tabular}{|c|c|c|}
\hline Item & Frequency & Percentage (\%) \\
\hline \multicolumn{3}{|l|}{ Gender } \\
\hline Male & 39 & 39.0 \\
\hline Female & 61 & 61.0 \\
\hline Total & 100 & 100.0 \\
\hline \multicolumn{3}{|l|}{ Age } \\
\hline $20-23$ & 14 & 14.0 \\
\hline $24-27$ & 44 & 44.0 \\
\hline $28-31$ & 25 & 25.0 \\
\hline $32-34$ & 17 & 17.0 \\
\hline Total & 100 & 100.0 \\
\hline \multicolumn{3}{|l|}{ Race } \\
\hline Malay & 92 & 92.0 \\
\hline Chinese & 5 & 5.0 \\
\hline Indian & 2 & 2.0 \\
\hline Others & 1 & 1.0 \\
\hline Total & 100 & 100.0 \\
\hline \multicolumn{3}{|l|}{ Education Level } \\
\hline SPM/STPM & 16 & 16.0 \\
\hline Professional Certificate & 4 & 4.0 \\
\hline Diploma & 23 & 23.0 \\
\hline Degree & 55 & 55.0 \\
\hline Master & 2 & 2.0 \\
\hline Total & 100 & 100.0 \\
\hline \multicolumn{3}{|l|}{ Marital Status } \\
\hline Single & 59 & 59.0 \\
\hline Married & 41 & 41.0 \\
\hline Total & 100 & 100.0 \\
\hline \multicolumn{3}{|l|}{ Employment Status } \\
\hline Permanent & 68 & 68.0 \\
\hline Contract & 14 & 14.0 \\
\hline Temporary & 18 & 18.0 \\
\hline Total & 100 & 100.0 \\
\hline \multicolumn{3}{|l|}{ Monthly Income } \\
\hline Less than 2,000 & 39 & 39.0 \\
\hline $2,001-3,000$ & 31 & 31.0 \\
\hline $3,001-4,000$ & 16 & 16.0 \\
\hline $4,001-5,000$ & 6 & 6.0 \\
\hline $5,001-6,000$ & 3 & 3.0 \\
\hline $6,001-7,000$ & 2 & 2.0 \\
\hline $7,001-8,000$ & 1 & 1.0 \\
\hline $8,001-9,000$ & 2 & 2.0 \\
\hline Total & 100 & 100.0 \\
\hline \multicolumn{3}{|l|}{ Position } \\
\hline Non-executive & 61 & $61.0 \%$ \\
\hline Executive & 33 & $33.0 \%$ \\
\hline Manager & 6 & $6.0 \%$ \\
\hline Total & 100 & $100.0 \%$ \\
\hline
\end{tabular}


Next is employment status. The lowest percentage is contract workers $(14.0 \%), 18.0 \%$ are temporary workers while $68.0 \%$ are permanent workers. A few number of respondent tend to have monthly income range between RM8,001 to RM9,000 (only 2.0\%), between RM7,001 to RM8,000 (1.0\%) followed with the highest percentage of monthly income range are from less than RM2,000 income that contribute $39.0 \%$ from total 100 respondents. Table 1 , shows the position of respondents at their company. The majority of respondents are non-executives that contribute of $61.0 \%$ of them followed by the executive position that represents $33.0 \%$. The least percentage is manager that only represents $6 \%$ of them.

\section{Reliability Analysis}

Table 2 below shows the reliability analysis used of the research that consists of independent variables and dependent variable. The reliability test is used to test the association between the groups of independent variables which are financial literacy, job satisfaction and savings behavior with the dependent variable i.e. retirement planning.

Table 2: Reliability Analysis

\begin{tabular}{lcc}
\hline & Number of Items & Cronbach's Alpha \\
\hline Independent Variables (IV) & $\mathbf{1 0}$ & $\mathbf{0 . 7 4 9}$ \\
Financial Literacy & $\mathbf{1 0}$ & $\mathbf{0 . 7 9 5}$ \\
Job Satisfaction & $\mathbf{1 0}$ & $\mathbf{0 . 7 9 7}$ \\
Saving Behaviour & & $\mathbf{0 . 8 3 2}$ \\
Dependent Variable & $\mathbf{1 0}$ & \\
Retirement Planning & & \\
\hline
\end{tabular}

According to the Table 2 above, the reliability for retirement planning is 0.832 which resulted in a good category. While the Cronbach's Alpha for financial literacy, job satisfaction and saving behavior are $0.749,0.795$ and 0.797 respectively.

\section{Mean Analysis}

Based on Table 3, the number of observation in this research is 100 respondents. The score from the Likert Scale are - "1" represented strongly disagree, "2" represented disagree, "3" represented agree and " 4 " represented strongly agree. Overall mean for the retirement planning is 3.0260 which clarify most of the respondents is agreed that they have a well planned for their retirement. While, mean 3.0040 for financial literacy, 3.0380 for job satisfactions and 3.1590 for saving behavior. The mean score for all the three independent variables shows that all the respondents are agree with the statements in the questionnaire.

Table 3: Mean Analysis

\begin{tabular}{lccc}
\hline & Number of Observation (N) & Mean & Std. Deviation \\
\hline Independent Variables (IV) & & & $\mathbf{3 7 9 7 7}$ \\
Financial literacy & $\mathbf{1 0 0}$ & $\mathbf{3 . 0 0 4 0}$ & $\mathbf{3 5 1 2 7}$ \\
Job satisfaction & $\mathbf{1 0 0}$ & $\mathbf{3 . 0 3 8 0}$ & $\mathbf{3 6 9 8 5}$ \\
Saving behavior & $\mathbf{1 0 0}$ & $\mathbf{3 . 1 5 9 0}$ & \\
Dependent Variable & & & $\mathbf{3 8 2 6 1}$ \\
Retirement planning & $\mathbf{1 0 0}$ & $\mathbf{3 . 0 2 6 0}$ & \\
\hline
\end{tabular}

\section{Pearson Correlation Analysis}

The Pearson correlation analyzes the direction, strength and the relationship between independent variable and dependent variable. It can be shown as in Table 4 below that there is positive moderate relationship and significant between independent variables (financial literacy, job satisfaction and saving behavior) and dependent variable (retirement planning). 
Table 4: Pearson Correlation Analysis

\begin{tabular}{lll}
\hline & Pearson Correlation & Sig. (2-tailed) \\
\hline & Retirement Planning (DV) & \\
Financial literacy & $.487^{* *}$ & .000 \\
Job satisfaction & $.401^{* *}$ & .000 \\
Saving behavior & $.477^{* *}$ & .000 \\
\hline ** Correlation is significant at 0.01 level (2-tailed) &
\end{tabular}

The correlation between financial literacy and retirement planning is 0.487 which have moderate relationship and it is significant. Besides that, job satisfaction and saving behavior are correlated with 0.401 and 0.477 with retirement planning respectively.

\section{Regression Analysis}

A multiple regression is used to shows the most factors that influence the retirement planning. It can be shown in Table 5 that there is strong statistical significance with $\mathrm{p}<0.001$ with $\mathrm{R}^{2}$ of 0.311 . It means that only 31.1 percent changes in dependent variable are because of independent variable.

Table 5: Model Summary

\begin{tabular}{|l|l|l|l|l|}
\hline Model & $\mathbf{R}$ & R Square & Adjusted R Square & $\begin{array}{l}\text { Std. Error of the } \\
\text { Estimate }\end{array}$ \\
\hline 1 & $.558^{\mathbf{a}}$ & .311 & .289 & .32255 \\
\hline
\end{tabular}

Table 6: Coefficients

\begin{tabular}{|c|c|c|c|c|c|c|}
\hline \multicolumn{2}{|c|}{ Model } & \multicolumn{2}{|c|}{ Unstandardized Coefficients } & \multirow{2}{*}{$\begin{array}{l}\text { Standardize } \\
\text { Cooefficients } \\
\text { Beta }\end{array}$} & \multirow[t]{2}{*}{$\mathbf{t}$} & \multirow[t]{2}{*}{ Sig. } \\
\hline & & B & $\begin{array}{l}\text { Std. } \\
\text { Error }\end{array}$ & & & \\
\hline \multirow[t]{4}{*}{1} & (Constant) & .913 & .332 & & 2.753 & .007 \\
\hline & Financial Literacy & .283 & .108 & .281 & 2.626 & .010 \\
\hline & Job Satisfaction & .135 & .114 & .124 & 1.191 & .237 \\
\hline & Saving Behavior & .270 & .110 & .261 & 2.451 & .016 \\
\hline
\end{tabular}

The results shown in Table 6 indicate financial literacy and saving behavior are significantly positive associated with retirement planning. Increases a unit of financial literacy will increase the retirement planning by 0.283 unit. As for saving behavior factor, as 1 unit increases, it will increase 0.270 unit retirement planning. This situation implies that the respondents acknowledged that saving behavior and financial literacy have an association with retirement planning.

\section{CONCLUSION}

Based on the findings above, it shows that there is positive and significant correlation between saving behavior, and financial literacy with retirement planning. Although there is significant association between financial literacy and retirement planning, it seems that the relationship is moderate. This finding is supported by Lusardi \& Mitchell (2011) that reveals that there is positively association between financial literacy towards retirement planning. Financial literacy also can be good association for financial decision making and strongly correlated to the planning for retirement (Lusardi \& Mitchell, 2007). Huston (2010) also believes that, there are relationships between financial literacy with the retirement planning management.

Furthermore, although there is positive association, but it is not significant with retirement planning. Research findings by Delpachitra \& Beal (2002) also reveals that there is strong correlation between probabilities of having a suitable job with the retirement planning by age of an individual. 
Saving behavior also has been accepted as one of factors that influencing retirement planning. It shows that there is a positive significant association but still the association is moderate. It is supported by Ntalianis \& Wise (2011) that states the saving behavior of individuals can be positively associated towards retirement planning with advance exposure to financial programs.

As for the recommendations, to attract more young professionals to save and invest for their future retirement planning, financial institutions should develop more attractive marketing strategy from time to time. With the attractive and in-depth explanations on important of investment and insurance, it will attract the young professionals to save. Encouragements from both government and private sectors are needed for the young professionals to plan for their retirement.

\section{REFERENCES}

Benartzi, S., \& Thaler, R. H. (2007). Heiristics and Biases in Retirement Savings Behavior. Journal of Economic Perspectives, 81-104.

Clark, A. E., Mavromaras, K., \& Wei, Z. (2014). Happy to Stay: Job Satisfaction and Retirement. NILS working paper series Working Papers No: 211/2014

Clark, R. L., d'Ambrosio, M. B., McDermed, A. A., \& Sawant, K. (2003). Financial education and retirement savings. Sustainable Community Development: What Works, What Doesn't and Why (pp. 143). Washington DC: Federal Reserve System.

Dendinger, V., Gary, A., \& Jacobson, J. (2005) Reasons for Working and Their Relationship to Retirement Attitudes, Job Satisfaction and Occupational Self-Efficacy of Bridge Employees. The International Journal of Aging and Human Development, 24.

DeVaney, S. A., \& Chen, Z. S. (2003, May 28). Job Satisfaction of Recent Graduates in Financial Services. Compensation and Working Conditions Retrieved March 16, 2017, from https://stats.bls.gov Lusardi, A. (2003). Planning and Saving for Retirement. Research Gate, 3-5.

Delpachitra, S., \& Beal, D. (2002). Factors Influencing Planning for Retirement. Economic Papers , $21(3), 1-13$.

Gedela, R. \& Prakasa, D.S. (2012). Determinants of Saving Behaviour in Rural and Tribal Households. International Journal of Research in Social Science, 2 (3), 109.

Huston S. J. (2010) Measuring Financial Literacy, Journal of Consumer Affairs. Volume 44, Issues 2 Summer 2010, page 296-316

Hung, A. A., Parker, A. M., \& Yoong, J. K. (2009). Defining and Measuring Financial Literacy. Rand Labor and Population, 3.

Klein, Mandell, L., \& Schmid, L. (2009). The impact of Financial Literacy Education on Subsequent Financial Behavior. Financial Counseling and Planning Education, 16-17.

Klein, Mandell, L., \& Schmid, L. (2007). Motivation and Financial Literacy. Financial Services Review, 107.

Lusardi, A., \& Mitchell, O. S. (2011). Financial Literacy Around the World: An Overview. NBER Working Paper Series, 5. 
Lusardi, A. \& Mitchell, O.S. (2011). Financial Literacy and Planning: Implications for Retirement Wellbeing. NBER Working Paper Series, 2-3.

Lusardi., \& Mitchell , O.S. (2007). Financial Literacy and Retirement Preparedness: Evidence and Implications for Financial Education. Business Economics, 39.

Lusardi, A. (2003). Planning and Saving for Retirement. Research Gate, 3-5.

Mbazigwe, C. (2013, October 07). The meaning of Financial Literacy and its Importance. Retrieved April 09, 2015, from futurpreneur Canada: http://www.futurpreneur.ca/en/2013/meaningfinancial-literacy/

Moorthy, K.M., Chelliah, D.T., Sien, C.S., Leong, L.C., Kai, N.Z., Rhu. W.C., et al. (2012). A Study on the Retirement Planning Behaviour of Working Individuals in Malaysia. International Journal of Academic Research in Economics and Management Sciences, 1(2), 55

Ntalianis, M., \& Wise, V. (2011). The Role of Financial Education in Retirement Planning. Australasian Accounting, Business and Finance Journal , 5 (2), 23-37.

Potts (2013). Retirement Plans and saving Decisions: Western Kentucky University, United States. Retrieved from

http://digitalcommons.wku.edu/cgi/viewcontent.cgi?article $=1440 \&$ context $=$ stu hon theses

Roscoe, J.T. (1975). Fundamental Research Statistics for the Behavioural Sciences, $2^{\text {nd }}$ edition. New York: Holt Rinehart \& Winston.

Shultz, K.S., \& Wang, M. (2010). Employee Retirement: A Review and Recommendations for Future Investigation. Journal of Management, 36(1), 175.

Stawski, R., Hershey, D., \& Jacobs-Lawson, J.M. (2007). Goal Clarity and Financial Planning Activities as Determinants of Retirement Savings Contributions. The International Journal of Aging and Human Development, 17. 